Journal of Applied Pharmaceutical Science Vol. 6 (02), pp. 135-140, February, 2016

Available online at http://www.japsonline.com

DOI: 10.7324/JAPS.2016.60221

ISSN 2231-3354 (cc) BY-NC-SA

\title{
Sildenafil reduces ischemia/reperfusion testicular injury after torsion/detorsion in rats
}

\author{
Marwa M. Abdel-Rahman ${ }^{1}$, Ayman M. Mahmoud ${ }^{2 *}$, Nevien M. Mostafa ${ }^{1}$, Mohamed E. Saleh ${ }^{1}$, Hassan M. Eissa ${ }^{1}$ \\ ${ }^{1}$ Physiology Department, Faculty of Medicine, Cairo University, Egypt. \\ ${ }^{2}$ Physiology Division, Zoology Department, Faculty of Science, Beni-Suef University, Egypt.
}

\author{
ARTICLE INFO \\ Article history: \\ Received on: 05/10/2015 \\ Revised on: 12/11/2015 \\ Accepted on: 30/11/2015 \\ Available online: 27/02/2016 \\ Key words : \\ Ischemia-reperfusion, \\ Testicular torsion; Sildenafil \\ citrate; Inhibin B; Oxidative
}

stress.

\begin{abstract}
This study was conducted to investigate the protective effects of sildenafil citrate on testicular injury after testis torsion/detorsion (T/D) in rats. Forty adult male Wistar rats were randomly allocated into four equal groups of ten rats each. Group 1 (Sham-operated); Group 2 (torsion for 2 hours and detorsion for 2 hours); Group 3, (torsion for 2 hours, sildenafil injection and detorsion for 2 hours), and Group 4 (sildenafil injection, torsion for 2 hours and detorsion for 2 hours).The levels of lipid peroxidation $(\mathrm{P}<0.001)$ and nitric oxide $(\mathrm{P}<0.01)$ were significantly increased in in the testis of group 2 rats. Testicular reduced glutathione and serum inhibin B levels were decreased significantly $(\mathrm{P}<0.001)$ after $\mathrm{T} / \mathrm{D}$. Administration of sildenafil either before or after torsion prevented the increase in lipid peroxidation and nitric oxide, and alleviated glutathione and inhibin B levels. Sildenafil also prevented ischemia/reperfusion cellular damage and histological alterations in testicular tissue. These results suggest that treatment with sildenafil citrate 2 hours before or after torsion could induce protective effects against ischemia/reperfusion injury.
\end{abstract}

\section{INTRODUCTION}

Testicular torsion is a well-known cause of testicle loss in newborns, children and adolescent boys. It is a true emergency urologic case and a delay in its management can lead to loss of the testicle (Visser and Heyns, 2003). The risk factors for testicular torsion are poorly understood. Torsion usually occurs in the absence of any precipitating event (Ringdahl and Teague, 2006). Environmental factors have been implicated by some authors and discredited by others. Srinivasan et al. (2007) speculated that an increased incidence of testicular torsion is seen with decreasing atmospheric temperature and humidity. Some reports have demonstrated that no statistically significant differences were to the seen with regard seasonal or monthly occurrence of testicular torsion (Williams et al., 2003). However, there is a cold weather seasonal trend for the torsion (Molokwu et al., 2011), and higher incidence rates of torsion have been

\footnotetext{
* Corresponding Author

Ayman M Mahmoud, Physiology Division, Zoology Department, Faculty of Science, Beni-Suef University, Salah Salim St.,62514, Beni-Suef, Egypt. E-mail: ayman.mahmoud@science.bs.edu.eg
}

reported during the colder months, especially December (Williams et al., 2003). It has been reported that 40 of 46 cases of torsion cases occurred when the ambient temperature was less than $2^{\circ} \mathrm{C}$ $\left(35.6^{\circ} \mathrm{F}\right)$ and the torsion occurred from a cold-induced contraction of the cremasteric muscles (Lyronis et al., 2009). Other predisposing factors include increased testicular volume, testicular trauma, a history of cryptorhidism, a spermatic cord with a long intrascrotal portion and testicles with horizontal lie (Ringdahl and Teague, 2006). The initial pathophysiologic event in testicular torsion is ischemia (I) followed by reperfusion (R); thus, testicular torsion/detorsion (T/D) is an I/R injury to the testis (Vigueras et al., 2004). T/D causes biochemical and morphological changes mediated by $\mathrm{I} / \mathrm{R}$ injury of the testicular tissue. I/R injury is associated with extreme production of reactive oxygen species (ROS) as well as reactive nitrogen species (Filho et al., 2004). Therefore, modulation of I/R-induced oxidative stress can offer an important strategy for preventing testicular injury in cases of torsion. Several studies have demonstrated a powerful protective effect of sildenafil against I/R injury in the testis in rat models (Beheshtian et al., 2008; Erol et al., 2009).Sildenafil, a phosphodiesterase 5 (PDE-5) inhibitor developed for erectile dysfunction (ED), has been reported to be effective in other 
medical indications such as type 2 diabetes mellitus, pulmonary hypertension, cardiovascular and spinal cord injury (Filho et al., 2004). The protective effect of sildenafil against I/R-induced tissue injury has been confirmed in other organs including, liver, colon and brain (Li et al., 2005; Zhang et al., 2006; Uzun et al., 2008).In this context, the present study was carried out to explore the protective effect of sildenafil, administered before and after torsion, on the testis after testicular I/R injury. This investigation could promote an understanding of its protective mechanism.

\section{MATERIALS AND METHODS}

\section{Chemicals}

Sildenafil citrate (Viagra) was purchased from Pfizer Inc. (Pfizer, Egypt). Glutathione (GSH), thiobarbituric acid (TBA), 5,5'-dithiobis-(2-nitrobenzoic acid) (DTNB), trichloroacetic acid (TCA), 1,1,3,3-tetramethoxypropane were supplemented by Sigma (USA). All other chemicals used were commercially available and of analytical grade.

\section{Experimental animals}

Forty white male albino rats weighting about $150-200 \mathrm{~g}$ obtained from the animal house of Faculty of Medicine, Cairo University (Egypt), were used in the present investigation. They were kept under observation for about 15 days before the onset of the experiment to exclude any inter-current infection. The chosen animals were housed in plastic good aerated cages at normal atmospheric temperature $\left(25 \pm 2^{\circ} \mathrm{C}\right)$ as well as normal $12 \mathrm{~h}$ light/dark cycle. Moreover, they were given access of water and supplied daily with standard diet of known composition. The experiments were conducted in accordance with the ethical guidelines for investigation of laboratory animals and were approved by Committee of Physiology Department, Faculty of Medicine, Cairo University.

\section{Experimental design}

The rats were divided into four groups $(\mathrm{N}=10)$ and anesthetized with Ketamine. Following anaesthesia, the skin of scrotal area was shaved and antisepsis was obtained by $10 \%$ iodine solution. A midline incision was made in the scrotum. In all the groups except for the sham-operated group, torsion was created by rotating the right testis $720^{\circ}$ clockwise for $2 \mathrm{~h}$. The torsion was maintained by fixing the testis in the scrotum with a silk suture, and the incision was closed. After a $2 \mathrm{~h}$ torsion period, the suture was removed, and the right testis was then detorted and replaced in the scrotum for $2 \mathrm{~h}$.

Group 1 (Sham-operated): Testes were taken out through the incision lines then replaced, and a silk suture was placed through the tunica albuginea.

Group 2 (Torsion/Detorsion [T/D]): Received intraperitoneal injection of saline $2 \mathrm{~h}$ before or after the torsion.

Group 3 (Torsion/Sildenafil/Detorsion [T/S/D]): Rats received $0.7 \mathrm{mg} / \mathrm{kg}$ body weight sildenafil citrate dissolved in saline intraperitoneally $2 \mathrm{~h}$ after the torsion.
Group 4 (Sildenafil/Torsion/Detorsion [S/T/D]): Rats received $0.7 \mathrm{mg} / \mathrm{kg}$ body weight sildenafil citrate dissolved in saline intraperitoneally $2 \mathrm{~h}$ before the torsion.

\section{Samples preparation}

At the end of the experiment, animals were sacrificed and blood samples were collected, left to coagulate and centrifuged at $3000 \mathrm{rpm}$ for $10 \mathrm{~min}$ to separate serum. Testes were immediately excised, cleaned and washed twice with ice-cold saline. The testes $(10 \% \mathrm{w} / \mathrm{v})$ were homogenized in chilled phosphate buffered saline (PBS), and then centrifuged at $3000 \mathrm{rpm}$ for $15 \mathrm{~min}$. The clear homogenates were collected and stored at $-20^{\circ} \mathrm{C}$ for biochemical analysis. Other samples from the testes were fixed in $10 \%$ buffered formalin for histological study.

\section{Biochemical assays}

\section{Assay of protein concentration}

Protein concentration was assayed in the testicular homogenate following the method of Bradford (1976).

\section{Assay of lipid peroxidation}

Lipid peroxidation was determined in the testicular homogenate by measuring malondialdehyde (MDA) according to the method of Preuss et al. (1998). Briefly, tissue homogenate was precipitated with $76 \%$ TCA and the mixture was centrifuged at $3000 \mathrm{rpm}$ for $10 \mathrm{~min}$. The supernatant was collected and mixed with $1.07 \% \mathrm{TBA}$, then incubated for $30 \mathrm{~min}$ at $80^{\circ} \mathrm{C}$ with shaking. After incubation, Cold 90\% TCA was added, and the absorbance was determined at $532 \mathrm{~nm}$. 1,1,3,3-tetramethoxypropane served as a standard.

\section{Assay of nitric oxide (NO)}

NO level was estimated in the testicular homogenate as nitrite according to the method of Montgomery and Dymock (1961). The assay is based on the Griess method which is a simple colorimetric reaction between nitrite, $\mathrm{N}$-(1-naphthyl) ethylenediamine and sulfonamide to produce a pink product with maximum absorbance at $543 \mathrm{~nm}$.

\section{Assay of reduced glutathione (GSH)}

GSH concentration was determined in the homogenate of testis according to the method of Beutler et al. (1963). Tissue homogenate was precipitated with a solution containing $1.67 \%$ glacial metaphosphoric acid, 0.2\% EDTA and $30 \% \mathrm{NaCl}$, and incubated for $5 \mathrm{~min}$ followed by centrifugation at $3000 \mathrm{rpm}$. The clear supernatant was mixed with $\mathrm{Na}_{2} \mathrm{HPO}_{4}$ and DTNB reagent. The absorbance was measured at $412 \mathrm{~nm}$.

\section{Assay of serum inhibin B}

Serum inhibin B concentration was determined using ELISA kit purchased from ABNOVA (USA), according to the manufacturer instruction. The assay is a quantitative test for detecting inhibin B peptide based on the principle of competitive enzyme immunoassay. 


\section{Histopathological study}

The testes were flushed with cold saline and then fixed in $10 \%$ buffered formalin for at least $24 \mathrm{~h}$. The specimens were then dehydrated in ascending series of ethanol, cleared in xylene and embedded in paraffin wax. Blocks were prepared and $4 \mu \mathrm{m}$ thick sections were cut by a sledge microtome. The paraffin embedded sections were deparaffinized, washed and stained with hematoxylin and eosin ( $\mathrm{H} \& \mathrm{E})$. The stained slides were examined under light microscope.

\section{Statistical analysis}

Statistical analysis was performed using GraphPad Prism 5 software (GraphPad Software, San Diego, CA, USA). Results were expressed as mean \pm standard deviation (SD) and all statistical comparisons were made by means of the one-way ANOVA test followed by Tukey's test post hoc analysis. A P value $<0.05$ was considered significant.

\section{RESULTS}

The results of testicular lipid peroxidation levels in all experimental groups are shown in Figure 1. MDA was significantly $(\mathrm{P}<0.001)$ elevated in group 2 (T/D) compared to group I (sham operated) $(9.17 \pm 2.04$ versus $1.11 \pm 0.14 \mathrm{nmol} / \mathrm{mg}$ protein). In contrast, MDA was significantly $(\mathrm{P}<0.05)$ decreased in group $3(\mathrm{~T} / \mathrm{S} / \mathrm{D})$ compared to group 2 (5.06 \pm 1.17 versus $9.17 \pm$ $1.18 \mathrm{nmol} / \mathrm{mg}$ protein). Group 4 (S/T/D) exhibited the same behavioral pattern where MDA was significantly $(\mathrm{P}<0.05)$ decreased when compared with group $2(5.09 \pm 0.89$ versus $9.17 \pm$ $1.18 \mathrm{nmol} / \mathrm{mg}$ protein).

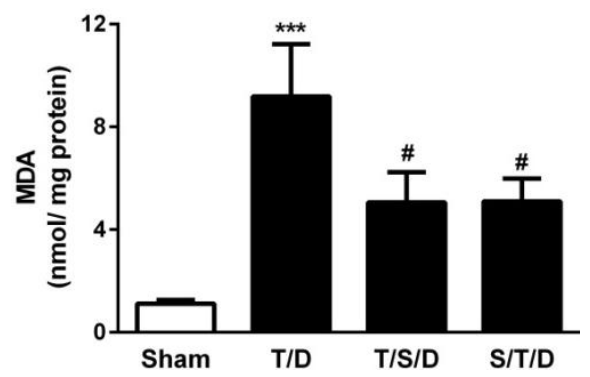

Fig. 1: Lipid peroxidation levels in testicular tissue of all experimental groups. Sildenafil treatment inhibits the increase of malondialdehyde in testes of rats. ***P $<0.001$ versus Sham and $\# \mathrm{P}<0.05$ versus T/D.

Nitric oxide levels, assayed as nitrite, showed a significant $(\mathrm{P}<0.01)$ increase in testis of group $2(\mathrm{~T} / \mathrm{D})$ rats $(0.78 \pm$ $0.09 \mu \mathrm{mol} / \mathrm{mg}$ protein) when compared with the sham operated group $(0.44 \pm 0.03 \mu \mathrm{mol} / \mathrm{mg}$ protein $)$, as depicted in Figure 2 . The testes of rats exposed to torsion then treated with sildenafil showed significant $(\mathrm{P}<0.05)$ decrease in nitrite content $(0.56 \pm 0.10$ $\mu \mathrm{mol} / \mathrm{mg}$ protein). Similarly, rats pretreated with sildenafil exhibited significant $(\mathrm{P}<0.01)$ decrease in testicular nitrite content $(0.48 \pm 0.09 \mu \mathrm{mol} / \mathrm{mg}$ protein $)$ when compared with the control group (T/D).

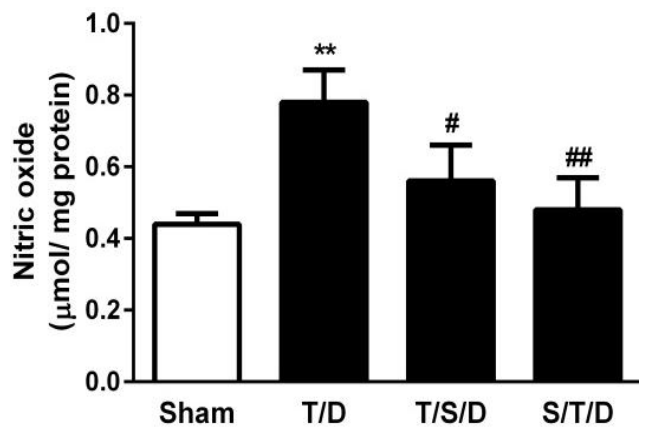

Fig. 2: Nitric oxide levels in testicular tissue of all experimental groups. Sildenafil treatment decreases nitrite in testes of rats. $* * \mathrm{P}<0.01$ versus Sham, and $\# \mathrm{P}<0.05$ and \#\#P<0.01 versus $\mathrm{T} / \mathrm{D}$.

GSH showed a significant decrease in group 2 (T/D) compared to group 1 (sham operated) $(22.07 \pm 2.66$ versus $43.21 \pm$ $1.38 \mathrm{nmol} / \mathrm{mg}$ protein). Rats treated with sildenafil after torsion (Group 3) showed significant $(\mathrm{P}<0.05)$ increase when compared with the T/D group $(32.90 \pm 1.55$ versus $22.07 \pm 2.66 \mathrm{nmol} / \mathrm{mg}$ protein), as represented in Figure 3. Sildenafil treatment before torsion $(\mathrm{S} / \mathrm{T} / \mathrm{D})$ markedly $(\mathrm{P}<0.05)$ prevented the decline in $\mathrm{GSH}$ content in testis of group 4 rats $(29.79 \pm 1.12 \mathrm{nmol} / \mathrm{mg}$ protein $)$.

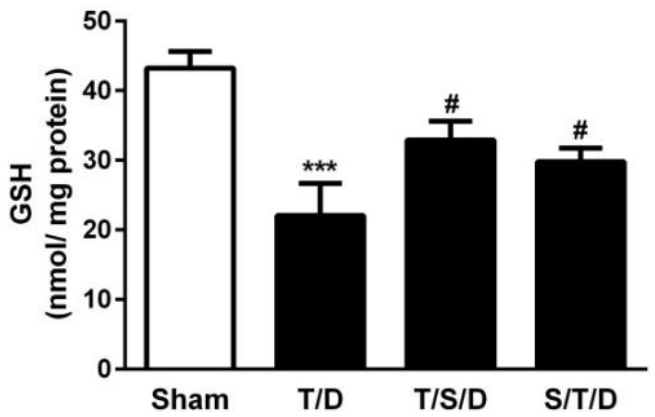

Fig. 3: Reduced glutathione levels in testicular tissue of all experimental groups. Sildenafil treatment prevents GSH decline in testes of rats. $* * * \mathrm{P}<0.001$ versus Sham and \#P<0.05 versus T/D.

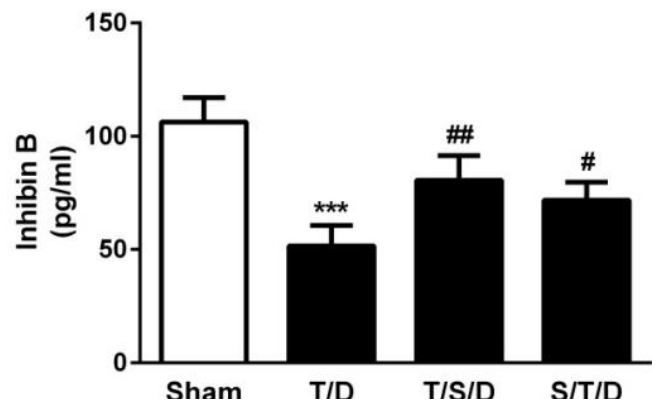

Fig. 4: Serum inhibin B levels of all experimental groups. Sildenafil treatment inhibits the decrease of inhibin $\mathrm{B}$ in serum of rats. $* * * \mathrm{P}<0.001$ versus Sham, and $\# \mathrm{P}<0.05$ and \#\#P<0.01 versus T/D.

The values of serum inhibin B concentration are shown in Figure 4. Inhibn $\mathrm{B}$ showed a significant $(\mathrm{P}<0.001)$ decrease in T/D group $(51.52 \pm 9.03 \mathrm{pg} / \mathrm{ml})$ when compared with the sham operated rats $(106.35 \pm 10.66 \mathrm{pg} / \mathrm{ml})$. 


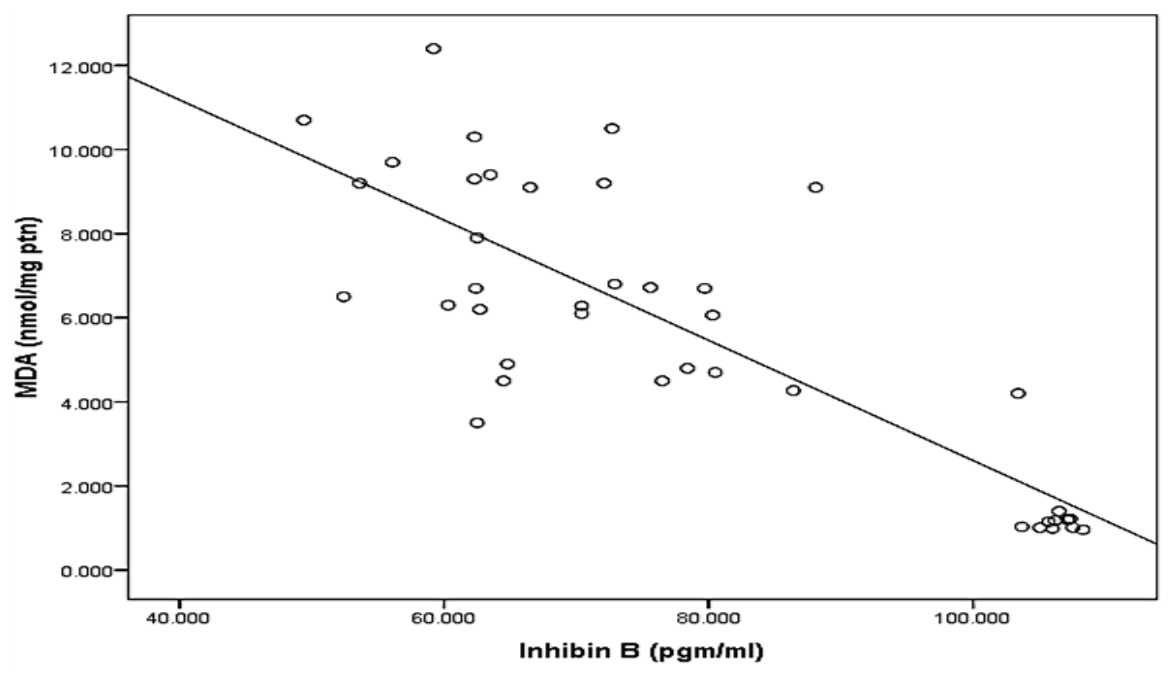

Fig. 5: Correlation between MDA and inhibin B in all the studied groups.

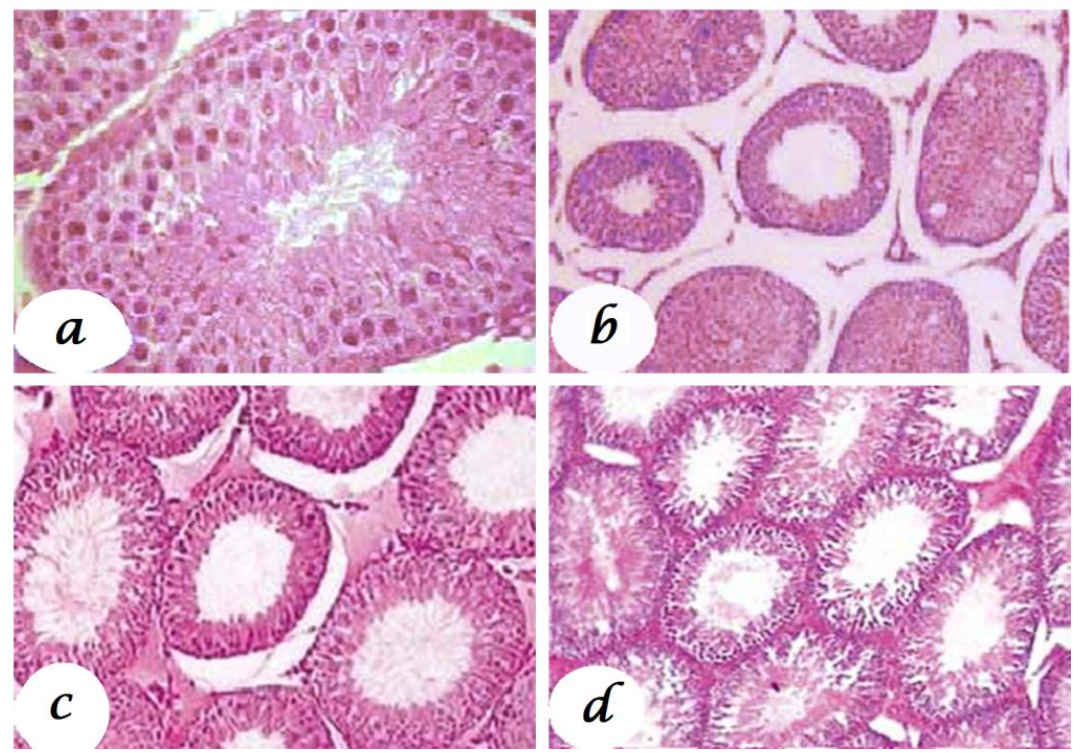

Fig. 6: Photomicrographs of H\&E stained testis sections of sham operated (a) showing normal histological structure, T/D (b) showing several lesions including degeneration, desquamation and disorganization in germinal cells, and interstitial oedema, T/S/D (c) and S/T/D (d) showing nearly normal histological structure.

Rats exposed to torsion then treated with sildenafil showed significant $(\mathrm{P}<0.01)$ increase in serum inhibin $\mathrm{B}$ level $(80.62 \pm 6.27 \mathrm{pg} / \mathrm{ml})$. Sildenafil pretreatment produced significant $(\mathrm{P}<0.05)$ increase in serum inhibin $\mathrm{B}(71.77 \pm 4.57 \mathrm{pg} / \mathrm{ml})$ when compared with the control group (T/D). As represented in Figure 5 , the results showed a strong negative correlation $(r=-0.819$ and $\mathrm{P}<0.001$ ) between testicular MDA and serum inhibin B among all experimental groups.

Histopathological analysis revealed normal histological appearance of testicular tissue of group 1 (Fig. 6a). In testis of group 2 (T/D), there were some histopathological changes including, disorganisation, degeneration and desquamation in germinal cells, and interstitial oedema, capillary congestion and hemorrhage (Fig. 6b). These histopathological changes were significantly less obvious in testicular tissue of group 3 (T/S/D) and group $4(\mathrm{~S} / \mathrm{T} / \mathrm{D})$ rats, as shown in Figure $6 \mathrm{c}$ and $6 \mathrm{~d}$, respectively. The histopathological alterations are summarized in Table 1.

Table 1: Histopathological lesions in testis of experimental groups

\begin{tabular}{lccc}
\hline \multicolumn{1}{c}{ Histopathological lesions } & T/D & T/S/D & S/T/D \\
\hline Degeneration in germinal cells & ++ & + & + \\
Reduction in germinal cell counts & - & - & - \\
Disorganisation in germinal cells & ++ & - & - \\
Desquamation in germinal ells & ++ & - & - \\
Interstitial oedema & ++ & + & - \\
Haemorrhage & ++ & - & - \\
\hline
\end{tabular}

\section{DISCUSSION}

Testicular torsion is the most prevalent genitourinary tract emergency of childhood and presumably a common surgical emergency in the adolescent age after acute appendicitis (Heyns 
and Visser, 2006; Saxena and Höllwarth, 2009). T/D causes biochemical and morphological changes mediated by I/R injury of the testicular tissue such as oxidative stress (Filho et al., 2004). Therefore, the present study was conducted to evaluate the protective effects of sildenafil, administered before and after torsion, on the testis after I/R injury.

In the present investigation, testicular T/D induced significant increase in lipid peroxidation and nitric oxide. Mammalian testes are highly sensitive to oxidative stress and particularly to lipid peroxidation due to their high concentration of polyunsaturated fatty acids in the plasma membrane (Hekimoglu et al., 2009). The fatty acids are an essential requirement for the male germ cell to maintain sperm functions. Some detrimental factors such as I/R injury in testicular torsion may cause DNA damage, inhibition of protein synthesis, corruption of the sperm formation cycle and abnormal spermatogenesis (Hekimoglu et al., 2009). A decrease in blood flow during ischemia causes hypoxia, which results in elevated levels of lipid peroxidation products such as lactic acid, hypoxanthine, and thiobarbituric acid reactive products in ischemic tissue (Akçora et al., 2008). Increased blood flow after ischemia leads to the formation of large amounts of oxygen and/or nitrogen-derived free radicals. Indeed, this causes further damage in the ischemic tissue and is known as reperfusion injury which induces oxidative stress (Akçora et al., 2008). In the same context, Lysiak et al. (2002) stated that I/R injury in many aspects resemble an inflammatory response characterized by recruitment of activated neutrophils and an increase in oxidative stress in the testis. The reperfusing neutrophils are potent sources of ROS (Turner et al., 2004) due to the increased nicotinamide adenine dinucleotide phosphate (NADPH) oxidase activity in ischemia (Salmasi et al., 2005). Moreover, lipid peroxidation activates mitogen-activated protein kinases (MAPKs), which are of vital importance for signal transduction pathways of germ cell apoptosis (Antonuccio et al., 2006; Payabvash et al., 2008).

NO has a central key role in modulating tissue injury and blood flow in normal and several pathological conditions (Arikan et al., 2010; Serarslan et al., 2010). In the present study, testicular NO showed a significant increase after T/D which could be attributed to overproduction of NO by activated inducible nitric oxide synthase (iNOS), and alterations in the blood flow (Andiran et al., 2000). High concentrations of NO, which is an important free radical, may cause DNA damage and cell death in testis.

Treatment of the T/D-exposed rats with sildenafil either before or after torsion decreased lipid peroxidation and $\mathrm{NO}$ in testicular tissue, suggesting a protective effect of sildenafil against I/R injury. Sildenafil has been reported to have inhibitory effects on mitochondrial superoxide radical production by enhancing cyclic guanosine monophosphate (cGMP) level and by inhibiting the expression of NADPH oxidase (Koupparis et al., 2005). It has also been shown that sildenafil decreases MDA level and increases the activity of antioxidant enzymes after spinal cord and testicular injury in rats (Erol et al., 2009). Other investigators have reported that sildenafil and other PDE inhibitors may have antiinflammatory activity through inhibition of ROS, leukocyte infiltration (Koupparis et al., 2005) and inflammatory cytokines (Toward et al., 2004).

GSH showed noticeable decline in testis of the rats subjected to T/D. On the other hand, administration of sildenafil before and after torsion prevented the decrease in GSH. Therefore, it seems that the protective mechanism of sildenafil on I/R injury is mediated, at least in part, via preventing GSH decline. In parallel to our study, Perk et al. (2008) have demonstrated that sildenafil citrate significantly increased the level of GSH and activity of the antioxidant enzymes and slightly decreased level of MDA at 6 and $24 \mathrm{~h}$ in the blood of healthy men. They suggested that the antioxidant effect of sildenafil citrate may be mediated via inhibition of PDE. In addition, Koupparis et al. (2005) reported an increase in red blood cell catalase activity after sildenafil treatment and have attributed their findings to the inhibition of free radicals and lipid peroxidation. It has also been shown that sildenafil and verdanafil increases activity of the antioxidant enzymes and decreases MDA level in testicular tissue after T/D in rats (Beheshtian et al., 2008; Erol et al., 2009).

Histopathological examination of testicular tissue from the rats exposed to T/D revealed increased degenaration in germinal cells, capillary congestion, interstitial oedema, and hemorrhage, which were ameliorated by sildenafil citrate. These findings show that sildenafil citrate reduced total tissue damage score in the testis of rats. These results are in agreement with those of Y1ldiz et al. (2011) who showed that administration of sildenafil $1 \mathrm{~h}$ before the detorsion significantly prevented IR-induced histological alterations. In the present study, sildenafil administration before and after torsion, reduced tissue damage in the testis of rats.

The protective effects of sildenafil on the testis after testicular I/R injury was further confirmed through assaying serum inhibin B. Inhibin B levels were reduced in serum of T/D-exposed rats. Reduced levels of inhibin $B$ have been described in adolescent boys after testicular torsion, particularly after orchidectomy (Taskinen et al., 2008). In addition, Ozkan et al. (2001) compared serum inhibin B levels to histopathologic parameters (Johnsen's score) on contralateral testicular damage after unilateral testicular torsion. They suggest that measurement of inhibin B levels to evaluate contralateral testicular damage after unilateral testicular torsion is more effective than histopathologic examination and this parameter evaluates complete testicular function. Administration of sildenafil restored the reduced levels of serum inhibin B. The current findings revealed a strong negative correlation between serum inhibin $B$ and levels of the lipid peroxidation marker MDA in all studied groups, suggesting a value of this test in evaluating testicular damage after T/D.

In conclusion, the present study suggests that treatment with sildenafil citrate $2 \mathrm{~h}$ before or after torsion could induce protective effects against I/R injury in the testis as demonstrated by increased serum inhibin B and testicular GSH, and decreased lipid peroxidation and NO levels. 


\section{REFERENCES}

Akçora B, Altuğ ME, Balci A, Hakverdi S, Yönden Z, Akbaş A, Oztürk A, Karazincir S, Ozyurt H. Gradual detorsion of torsioned rat testis attenuates ischemia reperfusion injury. J Pediatr Surg, 2008;43:18791884.

Andiran F, Okur DH, Kilinc A, Gedikoglu G, Kilinc K, Tanyel FC. Do experimentally induced ipsilateral testicular torsion, vas deferens obstruction, intra-abdominal testis or venous obstruction damage the contralateral testis through a common mechanism? Br J UrolInt, 2000; 85:330-335.

Antonuccio P, Minutoli L, Romeo C, Nicòtina PA, Bitto A, Arena S, Altavilla D, Zuccarello B, Polito F, Squadrito F. Lipid peroxidation activates mitogen-activated protein kinases in testicular ischemia-reperfusion injury. J Urol, 2006; 176: 1666-1672.

Arikan DC, Bakan V, Kurutas EB, Sayar H, Coskun A. Protective effect of tadalafil on ischemia/reperfusion injury of rat ovary. J Pediatr Surg, 2010;45:2203-2209.

Beheshtian A, Salmasi AH, Payabvash S, Kiumehr S, Ghazinezami B, Rahimpour S, Tavangar SM, Dehpour AR. Protective effets of sildenafil administration on testicular torsion/detorsion damage in rats. World J Urol, 2008;26:197-202.

Beutler E, Duron O, Kelly BM. Improved method for the determination of blood glutathione. J Lab Clin Med, 1963; 61: 882-888.

Bradford MM.A rapid and sensitive method for the quantitation of microgram quantities of protein utilizing the principle of protein-dye binding. Anal Biochem, 1976;72:248-254.

Erol B, Tokgoz H, Hanci V, Bektas S, Akduman B, Yencilek F, Mungan G, Mungan A. Vardenafil reduces testicular damage following 1schemı/ reperfusionınjury in rats. Kaohsiung J Med Sci, 2009; 25: 374 380 .

Filho DW, Torres MA, Bordin AL, Crezcynski-Pasa TB, Boveris A. Spermatic cord torsion, reactive oxygen and nitrogen species and ischemia-reperfusion injury. Mol Aspect Med, 2004; 25: 199-210.

Hekimoglu A, Kurcer Z, Aral F, Baba F, Sahna E, Atessahin A. Lycopene, an antioxidant carotenoid, attenuates testicular injury caused by ischemia/reperfusion in rats. Tohoku J Exp Med, 2009; 218: 141-147.

Heyns CF, Visser AJ. 2006. Testicular torsion. In: Schill WB, Comhaire FR, Hargreave TB, editors. Andrology for the clinician. Berlin: Springer. p. 134-161.

Koupparis AJ, Jeremy JY, Muzaffar S, Persad R, Shukla N. Sildenafil inhibits the formation of superoxide and the expression of gp47phos $\mathrm{NAD}(\mathrm{P}) \mathrm{H}$ oxidase induced by the thromboxane $\mathrm{A} 2$ mimetic, U46619, in corpus cavernosal smooth muscle cells. Br J UrolInt, 2005;96:423-427.

Li J, Fu P, Deleon M, French BA, French SW. The effect of Viagra (sildenafil citrate) on liver injury caused by chronic ethanol intragastric feeding in rats. Exp Mol Pathol, 2005; 78: 101-108.

Lyronis ID, Ploumis N, Vlahakis I, Charissis G.Acute scrotumetiology, clinical presentation and seasonal variation. Indian J Pediatr, 2009;76:407-410.

Lysiak JJ, Nguyen QA, Turner TT. Peptide and non-peptide reactive oxygen scavengers provide partial rescue of the testis after torsion. J Androl, 2002; 23:400-409.

Molokwu CN, Somani BK, Goodman CM. Outcomes of scrotal exploration for acute scrotal pain suspicious of testicular torsion: a consecutive case series of 173 patients. BJU Int, 2011;107: 990-993.

Montgomery HAC, Dymock JF. The determination of nitrite in water. Analyst, 1961; 86: 414-416.
Ozkan KU, Küçükaydin $\quad$ M, Muhtaroğlu S, Kontaş O. Evaluation of contralateral testicular damage after unilateral testicular torsion by serum inhibin B levels. J Pediatr Surg, 2001;36:1050-1053.

Payabvash S, Kiumehr S, Tavangar SM, Dehpour AR. Ethyl pyruvate reduces germ cell-specific apoptosis and oxidative stress in rat model of testicular torsion/detorsion. J Pediatr Surg, 2008;43:705-712.

Perk H, Armagan A, Naziroğlu M, Soyupek S, Hoscan MB, Sütcü R, Ozorak A, Delibas N. Sildenafil citrate as a phosphodiesterase inhibitor has an antioxidant effect in the blood of men. J Clin Pharm Ther, 2008;33:635-640.

Ringdahl E, Teague L. Testicular torsion. AmFam Physician, 2006;74:1739-1743.

Salmasi AH, Beheshtian A, Payabvash S, Demehri S, Ebrahimkhani MR, Karimzadegan M, Bahadori M, Pasalar P, Dehpour AR. Effect of morphine on ischemia-reperfusion injury: experimental study in testicular torsion rat model. Urology, 2005; 66:1338-1342.

Saxena AK, Höllwarth ME. 2009. Acute Scrotum. In: Puri P, Höllwarth M, editors. Pediatric surgery: diagnosis and management. Berlin: Springer. p. 927-34.

Serarslan Y, Yönden Z, Ozgiray E, Oktar S, Güven EO, Söğüt S, Yilmaz N, Yurtseven T. Protective effects of tadalafil on experimental spinal cord injury in rats. J Clin Neurosci, 2010;17:349-352.

Srinivasan AK, Freyle J, Gitlin JS, Palmer LS.Climatic conditions and the risk of testicular torsion in adolescent males. J Urol, 2007; 178: 2585-2588.

Taskinen S, Taskinen M, Rintala R. Testicular torsion: orchidectomy or orchiopexy? J Pediatr Urol, 2008; 4: 210-213.

Toward TJ, Smith N, Broadley KJ. Effect of phosphodiesterase5 inhibitor, sildenafil (Viagra), in animal models of airways disease. Am J Respir Crit Care Med, 2004; 169: 227-234.

Turner TT, Bang HJ, Lysiak JL. The molecular pathology of experimental testicular torsion suggests adjunct therapy to surgical repair. J Urol, 2004; 172:2574-2578.

Uzun H, Konukoglu D, Nuri MK, Ersoy EY, O” zc, evik S, Yavuz N. The effects of sildenafil citrate on ischemic colonic anastomotic healing in rats: its relationship between nitric oxide and oxidative stress. World J Surg, 2008; 32: 2107-2113.

Visser AJ, Heyns F. Testicular function after torsion of the spermatic cord. BJU Int, 2003; 92:200-203.

Williams CR, Heaven KJ, Joseph DB. Testicular torsion: is there a seasonal predilection for occurrence? Urology, 2003; 61: 638-641.

Yildiz H, Durmus AS, Imsek H. and Yaman I. Effects of sildenafil citrate on torsion/detorsion-induced changes in red blood cell and plasma lipid peroxidation, antioxidants, and blood hematology of male rats. Eur J Obstet Gynecol Reprod Biol, 2011; 159: 359-363.

Zhang RL, Zhang Z, Zhang L, Wang Y, Zhang C, Chopp M. Delayed treatment with sildenafil enhances neurogenesis and improves functional recovery in aged rats after focal cerebral ischemia. J Neurosci Res, 2006; 1:1213-1219.

\section{How to cite this article:}

Abdel-Rahman MM, Mahmoud AM, Mostafa NM, Saleh ME, Eissa HM. Sildenafil reduces ischemia/reperfusion testicular injuryafter torsion/detorsion in rats. J App Pharm Sci, 2016; 6 (02): $135-140$ 